\title{
Protest and Speech Act Theory
}

\author{
Matthew Chrisman (University of Edinburgh) and Graham Hubbs (University of Idaho)
}

During the final match of the 2018 FIFA World Cup, four women in security uniforms temporarily halted play early in the second half by running across the pitch. The goal of their intervention was not immediately obvious to the average spectator. At the moment it happened, it was not unreasonable to think that their aim was the attention of infamy. One of the women managed to high-ten French star Kylian Mbappé-perhaps she wanted to convey her affection for his play. After the match, a Facebook post clarified the point of their action: these were members of Pussy Riot, and they had disrupted the match to express dissatisfaction about and make political demands of Vladimir Putin's regime. The pitch invasion, it turned out, was an act of political protest. ${ }^{1}$

Our interest in this essay is to explicate the communicative structure of protest by recourse to speech-act theory. Even in non-verbal protests such as the Pussy Riot example, we will argue, protests contain an implicit communicative structure that speech-act theory can make explicit. Our analysis will also allow us to distinguish protest from similar sorts of complaints and demands. We proceed in three stages. First, we make some preliminary distinctions that help to identify protests as a complex, dual-aspect speech act. We next improve on this analysis by mobilizing the idea of a felicity condition of a speech act; specifically, we will argue that the speech act of protest can be understood as having a complex felicity condition stemming from the felicity conditions of making a specific kind of evaluative claim and a connected prescription. We then kick away the ladder of felicity conditions, further improving the analysis by arguing that the structure of the two connected communicative aspects of protest can be understood in terms of the normative statuses presumed by and affected through protest.

Our account here belongs to previous work we have done on the place of protest in non-ideal political theory. As we have discussed elsewhere (Chrisman and Hubbs 2018, 168), it is imaginable that an ideal polity would have no need, and so no place for, protest. In non-ideal polities, however, institutions that allow for the expression of at least some minority and dissenting opinions are needed if the polity is to be even minimally just. Legal protection for protest is one such institution; channels for recognizing the political legitimacy of some forms of civil disobedience are, arguably, another. John Rawls, for example, famously characterized civil disobedience as "one of the stabilizing devices of a constitutional system, although by definition an illegal one" (1999a, 336). It is clearly non-ideal to rely on illegal practices to "stabilize" a constitutional system, and it is also not ideal for legitimate opinions and demands to go unheard even if these are expressed legally. The theory we present below is meant to apply both to legal and illegal forms of the non-ideal speech act of protest.

\section{Protests: Some preliminary distinctions}

Protests come in varying degrees of complexity: a political rally, for example, can involve a variety of protesters protesting a variety of things. To take advantage of the resources of speech act theory, we will start by focusing on a single agent performing a single act of protest. In the standard individual case, this minimally involves conveying opposition to something and, in response, advocating for some sort of corresponding change. John Searle acknowledges these aspects when he writes that "...a protest

\footnotetext{
${ }^{1}$ https://www.theguardian.com/world/2018/jul/15/pussy-riot-claim-responsibility-world-cup-final-pitch-invasion
} 
involves both an expression of disapproval and a petition for change" (Searle 1975, 368), though we might add that expressing disapproval is one amongst potentially many ways a protest can convey opposition to something, and petitioning for change is just one amongst potentially many ways a protest can prescribe redress. Below, as we develop successive stages of the analysis, we will seek to refine these notions in order to distinguish protest from other related speech acts. For now, what is important to notice is that these communicative aspects of a protest are distinct, not only from each other, but also from the way in which a person protests, i.e., the means of her protest. When one protests, then, there is something one is against - the object — there is something one prescribes - the redress - and there is a way of communicating these connected stances-the means.

In some basic cases, the object that the protester opposes is some wrongdoing, and the redress the protestor pursues is simply an acknowledgement of and/or apology for that wrong. For example, protests of historical wrongs such as the internment of Japanese Americans during World War II have this flavor. A protestor expresses disapproval of what happened to these people, and they may want merely for this wrongdoing to be more widely acknowledged. In other basic cases, the object of a protest is a prohibition, and the redress the protester pursues is to lift that prohibition. For example, the object of a suffrage protest might be, e.g., the prohibition on women voting, and the corresponding redress might be to grant women the vote. In this case, the diverse acts of protest (carrying placards, chaining oneself to parliament, smashing windows, etc.) are various ways of communicating opposition to an aspect of the status quo and prescribing that it be changed-these are the various means of protest. In other cases, the object can be the status quo more generally, and the corresponding prescription may not be specifically defined. Tommie Shelby (2016, 223-225) and Candice Delmas $(2018,44-48)$ suggest that aspects of urban riots can be understood this way, as deeply frustrated reactions to gross and systemic injustice and as demanding that things, generally, change.

In some cases of protest, a single object may correspond with a number of distinct prescriptions for redress. Take, for example, a protest in response to the police killing of an unarmed person of color. Such a protest might have a variety of objects, e.g., the event of the killing, or the systemic behavior of the police. For the sake of simplicity, let the object in this case be the event of the killing. Even with respect to this single object, a protester might seek any of a variety of redresses: she might want the officer who committed the killing to lose his badge, or for that officer to be put on trial, or for the police chief to step down, or for the police force to undergo an independent investigation, or all of these, or something else. A given object of protest, then, might be connected to a variety of prescribed courses of redress.

Because of this, as mentioned above, an event in which several protesters participate may be united by a single object but may involve several different individual acts of protest, each with its own prescription for redress. Moreover, such events may involve acts that differ not just in their prescriptions for redress but also in their objects. At anti-globalization protests, for example, one may find objects ranging from specific trade treaties to the activities of specific corporations to the laws governing those corporations to the governments that produce those laws to the politicians that make up those governments. Each of these objects, in turn, might be connected to a multiplicity of corresponding demands.

Moreover, a single protester with a single object and a single desired redress may employ a multiplicity of means over the course of an act of protest. Staying with the police-protest example: suppose a protester participates in a rally whose explicit demand is to have charges brought against a specific police officer for a shooting. This protester may march legally in the street, or they may do so illegally, and as they march either legally or illegally, they may chant, and/or carry a sign, and/or perform a symbolic gesture (e.g., put their hands up in the air while saying "Hands up; don't shoot"). Each of these actions involves the same object and the same prescription, but they are different means of drawing attention to the object and pursuing the redress. In Pussy Riot's World Cup protest, some members invaded the pitch of the final match, while another made a Facebook post to clarify the 
point of the invasion. These are, clearly, separable actions; together, they conveyed opposition to the Putin regime and prescribed specific corresponding remedies.

For some acts of protest it is useful to distinguish between the direct communicative goal of protest and the broader goals of the act of communication. This distinction is helpful, for example, for characterizing the role of solidarity in protesting. Suppose someone who is not a Muslim protests an immigration ban on Muslims. Their communicative goal is to object to the ban and to demand that it be changed; however, their broader goal in performing that communicative act might be to show the Muslim members of their community that someone who is not directly affected by the ban stands in solidarity with them. The redress that is prescribed by an act of protest, then, need not be the only communicative goal that the protesting agent pursues by her protest.

It is also useful to distinguish between the intended audience of an act of protest and the agent who is called upon to perform the protest's redress, whom we shall call the addressee of the protest. In some cases, the protest's addressee may not be the primary intended audience. A group of citizens in a small Idaho community may gather to protest Donald Trump's immigration policies even if none expect that Trump himself will ever become aware of the protest. Their primary audience may be the members of their community even as they call on their addressee (Trump) to change his policies. For this act to count as a protest, however, the protestors must be committed to thinking Trump could come to know about their demands and so in that weak sense be a possible member of the audience. Moreover, for an act to count as a protest, it must be sufficiently public for some general audience to be aware of the protest. Complaining to one's co-workers about a company policy is not protest, and telling one's boss privately and confidentially that one disagrees with the policy is not protest, but expressing this disagreement with a megaphone outside of company headquarters is.

When we speak of a protester's intended audience, we do not mean to suggest that a protester must have someone explicitly in mind when protesting. The intended audience might be implicit; the protester might only think explicitly of the protester if asked, "Who do you want to hear your protest?" Moreover, the intended audience need not be very specific - it might be, e.g., whoever will listen or the public. On some occasions, however, the intended audience may explicitly include specific individuals: a group of students might, e.g., protest explicitly and specifically to a university president (who, here, would also be the addressee) to demand that a building's name be changed.

As we understand the practice, protests necessarily involve different relations of power, or authority, or something similar, between the protester and the agent from whom redress is desired. We take no stand here on what hierarchical notion-power, or authority, or something else-best articulates this difference. The examples above demonstrate what we have in mind: consider the relation between the Russian government and Russian citizens, or the relation between a government and those it governs who lack the right to vote, or the relation between a police force and the people over whom it enforces the law. In each of these, the addressee has authority or power that the protesters lack, and the protesters are demanding that that authority or power be exercised in a way it has not been and/or is not being exercised. To put the point starkly: Pussy Riot can protest Putin's politics, but it is impossible for Putin to protest Pussy Riot's politics. If he objects to something they do, he does not protest that action; if he wants redress, he can effect it directly through, e.g., imprisonment.

All of the examples of protest we have considered so far are explicitly political. However, if there are non-political hierarchies, then non-political protest is possible as well. A recreational youth football team might not be a political entity; if it is not, its players can non-politically protest by, e.g., sitting down when the coach instructs them to run laps around the pitch. This act of sitting could be a mere display of laziness or exhaustion, but it could also have the communicative elements of a protest, when, for example, it expresses opposition to the coach's command and prescribes that the coach be less demanding with his lap-running requirements, either just in this specific instance or more generally. Our focus for this essay will remain fixed on explicitly political protest, but we intend what we say to be sufficiently general to allow for non-political protest as well. 


\section{Felicity conditions, uptake, and the speech act of protest}

So far, the first stage of our analysis has been to trace out some initial implications of the idea that a protest can be viewed as a complex speech act, where a person takes some communicative means in an effort to (i) convey opposition to some object and (ii) prescribe redress related to that opposition. This analysis, however, is not sufficiently precise, for some communicative actions that aim at both (i) and (ii) do not seem to be protests. Imagine a traveler who has been bumped off of an overcrowded flight in accordance with the terms and conditions of his ticket. Imagine this traveler yelling at an airline attendant, saying, "This is crap! I have to make it to my destination tonight. You have to put me on this flight!" This conveys opposition to the travel situation and prescribes a course of redress, but it is not obviously a protest; indeed, we think there is good reason not to group this case with the examples of protest from the previous section. In this section, we will argue for this claim by pursuing a second stage of the analysis, in which we attempt to identify some felicity conditions distinguishing protest from other similar communicative actions.

J. L. Austin $(1975,14-24)$ argued influentially that we can identify felicity conditions for different kinds of speech acts. Felicity conditions themselves can be divided into distinct classes. One familiar class comprises those conditions that, when violated, undermine one's counting as performing the act one aims to perform in speaking. For example, imagine a priest in Belize who attempts to wed two people of the same sex. The priest does not have the legal authority to wed these people, for homosexual marriage is illegal in Belize. So, when he says of this couple, "I now pronounce you married," he has not wed them, for the felicity conditions for wedding a couple have been violated. To count as wedding two people in Belize, one must have a certain normative status (i.e., one must be legally authorized to do so), and one must follow the rules in performing the wedding ceremony. Failure to have the needed status or to follow the ceremonial rules results, not in a bad marriage, but in no marriage at all. Austin (1975: 16-18) calls these sorts of "unhappy" speech acts misfires; because these speech acts fail to satisfy norms that constitute the intended action type, the acts do not count as instances of the relevant type.

A different kind of felicity condition derives from norms whose applicability is partially constitutive of an action counting as a specific type of speech act. One can fail to meet this sort of norm while still counting as performing the relevant speech act; in such a case, one just counts as performing the act poorly or incorrectly relative to the norm. ${ }^{2}$ To see what we have in mind, consider the view that truth is a constitutive aim of assertion. ${ }^{3}$ Someone who holds this view does not claim that, in order to count as an assertion, a speech act must be true; rather, the idea is that the fact that someone's saying something is correct/incorrect in virtue of its relation to truth is (part of) what makes that speech act an assertion. On this view, it is the applicability of, not conformity to, the norm "it ought to be true" that is partially determinative of something's counting as an assertion. Speakers need not themselves endeavor to speak truly for their speech to count as assertion, as evidenced by lying. ${ }^{4}$ What is important, rather, is the type of normative evaluation that is appropriate for the speech act. Taking this position allows one to distinguish assertion from other uses of declarative sentences, such as

\footnotetext{
${ }^{2}$ Failure to meet these norms is related to the other species of "unhappy" speech-acts Austin describes as abuses. For example, a promise made with no intention to do what one promises still counts as a promise, but the speaker abuses the norm of promise making that says one ought to promise to do things only if one intends to do them. We remain unsure how exactly to think about Austin's category of abuses. There are violations norms whose applicability is partially constitutive of a speech-act's being a particular type of speech act that are nonetheless difficult to conceptualize as abuses.

${ }^{3}$ See Michael Rescorla (2009) for discussion of various proponents of this idea. For a more recent discussion of the topic, see Sanford Goldberg (2015).

${ }^{4}$ For more on this, see Eliot Michaelson and Andreas Stokke's contribution to this volume.
} 
hypothetical supposition and overt fiction. This is why, when Doyle says, "Holmes lives on Baker Street," it is not appropriate to wonder whether what he said is true, for Doyle is not asserting that Holmes lives on Baker Street but rather is telling a fictional tale.

Another idea from speech-act theory is relevant here: for some speech acts, only minimal uptake on the part of the audience is required for them to count as instances of their kind. For example, for a speech act to count as a warning, it is enough for the audience to understand that the speaker, in saying what she is saying, is trying to alert the audience of some perceived danger. When Cassandra admonishes the Trojans not to take the giant horse left behind by the Greeks, she succeeds in warning the Trojans even though they ignore her advice. By contrast, if we describe the same act as persuading the audience to guard against the danger, then more audience uptake is required for the speech act to satisfy this description; the audience must become convinced to react in accordance with the warning. Although Cassandra manages to warn the Trojans, she does not persuade them to leave the horse outside the city walls, for they do not heed her warning. ${ }^{5}$ We can mark this difference in uptake between warning and persuading by comparing the intelligibility of the following sentences. "Cassandra warned the Trojans, but they didn't listen to her" is intelligible - it indicates that the Trojans understood Cassandra's warning but did not heed it. By contrast, "Cassandra persuaded the Trojans, but they did not listen to her" is much more difficult to make sense of, as the latter clause appears to preclude the former. ${ }^{6}$ We will return to this distinction at the end of this section.

With these points in mind, let us return to our disgruntled traveler. The object of his anger is the weather delay. He expresses disapproval of his travel situation and demands redress. Why not count this, then, as a protest, grouping it together with the examples from the previous section? In discussing civil disobedience, which we view as a species of protest, Rawls provides a clue. He writes: "...it is important that the action be properly designed to make an effective appeal to the wider community" (1999a, 330). Rawls is imagining protest actions as making appeals to one's constitutional community, wherein there exists some overlapping conception of the basic principles of just interaction. For this reason, famously, in $A$ Theory of Justice he claims that civil disobedience should address "the sense of justice in the community, an invocation of the recognized principles of cooperation amongst equals" (1999a, 337). In order to cover other sorts of community, and other sorts of protest, one might propose something more general than what Rawls says here. ${ }^{7}$ That is, one way to explain why the traveler counts as merely complaining rather than protesting is to argue that protest involves conveying opposition to something, not merely by expressing disapproval (however justified), but by doing so in a way that amounts to publicly making an evaluative claim, one which appeals to a wider audience, and in effect says that the object of protest is in some way unfair or unjust. ${ }^{8}$ To be more precise, the

\footnotetext{
${ }^{5}$ Following Austin, this difference between warning and persuading is sometimes understood as the difference between illocutionary and perlocutionary acts. In our experience, the terminology is misleading, in that it suggests a binary distinction when it seems more plausible that there is a spectrum between speech acts that require minimal audience uptake and those that require significant audience uptake.

${ }^{6}$ This form of analysis is inspired by Moore's Paradox. G. E. Moore argues that there is something absurd in saying "I went to the pictures last Tuesday, but I don't believe that I did" (Moore 1942, 543). This absurdity, however, does not appear to be that of a straightforward contradiction, so the philosophical task is to locate the source of the absurdity. The structural parallels between Moore's sentence and the sentences above should be clear. For recent discussions of Moore's Paradox itself, see Mitchell Green and John Williams (2007) and Jack Woods (2014). For another example of extending the analytic strategy of Moore's Paradox, see Graham Hubbs (2019).

${ }^{7}$ Rawls has a few slightly more general things to say in The Law of Peoples. For example, when discussing the structure of "decent consultation hierarchy," he says that judges must be willing to listen to and to respond to dissent, and if dissenters do not agree with the judges' decisions, the dissenters may "renew their protest," which "is permissible provided it stays within the basic framework of the common good idea of justice" (1999b, 72). These remarks go undeveloped, however; here, we attempt to work out some of the details of a more general account.

${ }^{8}$ In an earlier discussion, we say that the object must explicitly concern justice, and we defend this claim by explaining how broadly we understand the concept of justice (Chrisman and Hubbs 2018, 176). This risks inviting confusion. We hope to avoid any such confusion here by spelling out the relevant idea in terms of agent-neutral normative statuses, as we do in the next section.
} 
present suggestion is that, unlike a mere complainer, a protestor presumes there is some overlapping conception of what is unfair or unjust between them and their audience, and they are publicly characterizing (at least implicitly) the object of protest as falling under this conception. The traveller's travel situation may be highly annoying to him, but it is implausible to view his expression of disapproval as designed to make an effective appeal to some overlapping conception of what is unfair or unjust of the wider community.

We are not claiming that the relevant conception of what is unfair or unjust needs to be very precise or explicit in the minds of protestors. Instead, we are suggesting that this kind of grounding is part of the normative structure of the social practice, rather than a conscious feature of the intentions of those engaged in the practice. By comparison, those who engage in assertion might not have a very precise understanding of truth or have some explicitly self-conscious intention to say what is true. Mirroring the metaphor of assertions constitutively aiming at truth, we can then generate a more precise analysis as follows: protests constitutively aim at truth about what is unfair or unjust relative to some conception of what is fair or just that is presumed to overlap with the protest's audience. This can be only half the story, however, for along with this evaluative component, and as we have been emphasizing throughout, protests also have a prescriptive component. Continuing with a generalization of the Rawlsian idea, we claim that protests prescribe redress in a specific way, namely as a way to address the unfairness or injustice claimed. In the language of constitutive aims, the present suggestion is that, in addition to constitutively aiming at truth about what is unfair or unjust, protests also aim at the imposition of an obligation for their addressee to do something about the object of protest. Reformulated as a pair of 'ought' claims, the present suggestion is that the negative evaluation that the object is unfair or unjust implicit in a protest ought to be true, and the prescribed redress in a protest ought to be such so as to impose an obligation on the protest's addressee.

Putting together the two halves of the story, we get the view that the applicability of this pair of norms is part of what makes a speech act a protest. No one, the disgruntled traveler included, presumes that bad weather is unfair or unjust or that his demands impose any justice- or fairness-based obligation on the airline employees. His complaints and demands about his travel situation are thus not even subject to the speech act norms constitutively applying to protest, and this provides grounds for not classifying his action as a protest. As is the case with assertion, a particular protestor might not themself explicitly aim at conforming to the constitutive norms, but the present suggestion is that the fact that their speech act is understood by participants in the social practice to be evaluable with respect to these norms is part of what constitutes it as a protest.

In speaking only of a presumed overlapping conception of what is unfair or unjust, someone pursuing this broadly Austinian analysis of protest would have to acknowledge that the intended audience and/or addressee of a protest can disagree with the protestor's view that the object of protest is unfair or unjust. If I protest an extant law that you think is perfectly good but I think is unjust, you are likely to be unpersuaded by my protest, because we do not agree about the justice of the law. For my speech act to count as a protest, it must be clear that I hold the law in question to be unjust and think that you should agree. If you and I do not already have a common view about the injustice of a situation - in this case, whether the relevant law is or isn't just - then I need you to come to share my view if I want my protest to succeed. There are at least two ways I can attempt this. I can seek a broader conception of justice we already share and try to persuade you that, according to it, the law I am protesting is unjust by the lights of this conception and the redress prescribed is a reasonable way to respond. Alternatively, I can attempt to bring you over to my conception of what is unjust, or at least the relevant part of this conception for evaluating the object of protest and the redress pursued. My presumption, then, is either that our conceptions of justice already overlap in some relevant respect or that you should come to share at least this element of my conception of what is unjust.

Even if, on some occasion, this presumption fails to hold-i.e., even if the audience never comes to share an overlapping conception of what is unfair or unjust - the protester may still succeed in performing an act of protest. Indeed, even if the protestor knows the presumption of an overlapping 
conception of what is unjust will remain false with respect to a particular audience, the protestor may still succeed in performing an act of protest. ${ }^{9}$ Like warnings, protests are speech acts whose execution requires minimal audience uptake. Returning to the distinction illustrated above by the Cassandra examples: "The crowd protested Bush's proposal to invade Iraq, but the White House didn't listen" is intelligible. For a speaker here (e.g., some member of the crowd) to count as protesting, her audience (e.g., Bush and/or members of his administration) must understand why she is saying what she is saying but not necessarily change their minds as a result of this understanding. More specifically, the audience must understand what the speaker is saying as the expression of negative evaluative claim about something being unfair or unjust and as prescribing some redress to this presumed unfairness or injustice. It is not, by contrast, necessary that the audience be persuaded of the unfairness or injustice of the object or the reasonableness of the prescribed redress as a way to address this purported unfairness or injustice. One counts as performing a speech act of protesting even if one fails to convince the audience of either of these points.

\section{Protest and the pragmatic topography of speech acts}

We have just examined the possibility of improving the speech-act analysis of protest by drawing on the Austinian notion of felicity conditions. We appealed to an analogy with assertions, which have commonly been thought to be partly constituted by the applicability of a norm of truth, to suggest that protests have a similar felicity condition: they ought to convey true claims about something's being unfair or unjust relative to a presumed overlapping conception of fairness or justice. On reflection, however, this doesn't seem quite right. For one thing, not all protests are obviously about unfairness or injustice: some have suggested to us that one protest the color of the national team's football jersey or the closing of a widely beloved bar in one's neighborhood without obviously making a claim about what is unfair or unjust relative to the presumed overlapping conception of fairness or justice. ${ }^{10}$ For another thing, it is not clear, at all, that protests typically make claims (even just implicitly) about what the presumed shared conception of fairness or justice would rule out. Instead, what seems crucial to a speech act's being a protest is that protestors make a negative evaluation that purports to be grounded in the sorts of considerations that could convince one's audience to agree with the evaluation. Perhaps such negative evaluations always come from some particular normative perspective, and perhaps one's audience will come to share the negative evaluation only if they consider the issue from a relevantly overlapping normative perspective, but it does not seem that protests typically aim at truth about normative perspectives.

Another worry about the previous section's analysis concerns the idea that protests are infelicitous if they do not (at least implicitly) impose obligations of redress on their addressee. On reflection, this too can't be quite right. Normally we think the speech act of commanding is successful only if it imposes obligations, but in order for this to happen, the speaker must have some kind of authority

\footnotetext{
${ }^{9}$ Indeed, we suspect this is part of the story of why influential protests have the persuasive power that they do. By presuming an overlapping conception of what is unfair or unjust, a protestor treats that conception as not at issue in making their claims and prescriptions, which is a common rhetorical technique for motivating an audience through nonrational means to agree with something by taking it for granted. See Rae Langton and Caroline West (1999, 309311) discussing pornography, Stephen Finlay $(2014,184-188)$ discussing moral ought-claims, and Jason Stanley (2015, ch. 4) discussing propaganda for similar ideas about the persuasive power of various forms of pragmatic presupposition.

${ }^{10}$ We wish to remain neutral about the correctness of applying the English word 'protest' to these cases, and we don't see our methodology as one of refining necessary and sufficient conditions for the correct application of this word in light of competent speaker intuitions. Our hope is to identify a recognizable normative phenomenon of which political protests of the sort we mentioned at the beginning of this paper are paradigms but which might admit of other nonpolitical examples.
} 
over the addressee. When it comes to protests, however, the power relation is clearly different. Putin has a kind of authority over Pussy Riot, and because of this, as noted at the end of section 1 , he cannot protest their actions; it is only those who lack control or authority over the addressee who are in a position to protest. But if they lack control or authority, how could they impose obligations on the addressee of their protest? And how could doing so be a constitutive aim of the speech act of protest?

To address these concerns, we to replace the idea of felicity conditions with a more precise tool from speech act theory that builds on the idea that assertion can be helpfully characterized in normative scorekeeping terms. ${ }^{11}$ The basic idea is that certain conditions must obtain in order for a speaker to be entitled to assert something, and when a speaker is presumed to assert something with entitlement, then other normative statuses change in rule-governed ways. ${ }^{12}$ Rebecca Kukla and Mark Lance (2009) have suggested a generalization of this idea, whereby every speech act is characterized in normative scorekeeping terms. Our competence with the linguistic practices in which we take part can then be viewed as a matter of implicit scorekeeping, and particular speech acts can be abstractly characterized not in terms of the conditions under which they are felicitous but in terms of normative functions from input conditions for a speaker's entitlement to perform the act in question to output statuses affected by a presumed entitled performance of that act. This is what we might term a normative functionalist approach to understanding the nature of speech acts, because it replaces felicity conditions with normative functions in order to individuate speech acts.

More precisely, for any particular speech act, we can attempt to characterize the facts, considerations, or reasons that entitle one to perform a speech act. These facts, considerations, and reasons are going to be diverse and often particular to specific speech situations, but we might attempt to articulate partially constitutive entitlement conditions for various speech act kinds. However, this is only half of the normative functionalist story. The other half is the outputs-that is, the entitlements, obligations, and reasons to do things, including but not limited to performing other speech acts—-that are generated by an entitled performance of a speech act. Again, these are going to be diverse and often particular to specific speech situations, but we might attempt to articulate the general kinds of entitlements, obligations, and reasons the generation of which is partially constitutive of various speech act kinds. By pairing these up with constitutive entitlement conditions and comparing and contrasting speech act kinds in terms of their input-output functions between constitutive normative statuses, we can generate what Kukla and Lance call a "topography" of the normative terrain of linguistic practices.

For example, rather than say that an assertion is felicitous only if true, we can instead say that (input:) an assertion is what it is because its being true is (a central part of) what one presumes when one takes its performance to be entitled. Arguably, at least in core cases of assertion, the speaker incurs an obligation or at least a reason to defend their assertion or retract it when presented with reasonable challenges. Moreover, (output:) accepting an assertion as entitled is accepting its content as true and holding that others are also entitled to accept its content as true. This, in turn, supplies a reason for anyone to think it true. Similarly, rather than say that a command is felicitous only if made with authority to impose obligations, we now say that (input:) a command is what it is because the speaker's having authority to impose obligations on the addressee is (a central part of) what one presumes when one takes its performance to be entitled. Moreover, (output:) accepting a command as entitled is accepting that the addressee of the command has acquired an obligation to do what they have been commanded to do. Those examples are overly simplified and might need "ceteris paribus" or "pro tanto" clauses to specify the normative functions constituting assertion and command more precisely, but the general normative functionalist strategy is to individuate different speech acts in the linguistic

\footnotetext{
11 See especially David Lewis (1979), Robert Brandom (1983, 1994), and John MacFarlane (2011).

12 The notion of entitlement here is practice-internal. There may be reasons of morality, prudence, law, or etiquette that someone shouldn't assert something that they are entitled, as far as the practice of assertion goes, to assert. However, that doesn't mean that entitlement conditions have to do only with what people have and will say. For example, one might suggest that the practice of assertion is such that one is entitled to assert only that for which one justifiedly believes or knows to be true.
} 
practice of which they are a part by identifying what it takes to be entitled to perform the speech act and what such a performance does to the downstream normative statuses of speaker and audience.

On this normative functionalist conception of linguistic practice, speakers and hearers "keep score" on ongoing conversations by tracking what speech acts are being performed, which they do by understanding (at least implicitly) the associated function characterizing what the normative score has to be for the speaker to be entitled to perform the act in question and what effect such performance has on the normative score. Different speech acts are individuated by different normative functions.

In addition, at a very abstract level, the input and output normative statuses that individuate speech acts can be usefully classified as particular or general depending on whether having them depends on something particular to the person who has them above and beyond their generic status of being the speaker of a language. For example, if we say that an assertion presumes entitlement based in the truth of what is said, and we think that what is true for one speaker is true for any other speaker (i.e. that the relevant truth isn't speaker-relative), then assertions presume a general entitlement in the sense that this entitlement is available to anyone if it is available to the speaker. Because of this, in asserting $\mathrm{p}$, a speaker is in effect accepting that the normative score is such that any other speaker would also be entitled to assert p. Moreover, if we say that, when one successfully asserts something, others become entitled to believe what was asserted, then this output normative status is also general in the sense that it doesn't depend on who it is that's acquiring the entitlement. If one person gets this new normative status by virtue of hearing and understanding the assertion as an assertion, then so does anyone else who hears and understands the assertion as an assertion. In successfully asserting, a speaker gives anyone who recognizes the assertion a reason to believe what is said, not just particular people, such as friends or subordinates or the Queen.

By contrast, as already observed, the speech act of commanding presumes entitlement based in the speaker's authority over a particular audience member, viz., the addressee. So entitlement to command someone to do something is particular in the sense that it it depends on something particular to the speaker, namely their relationship to the addressee, which the speaker need not presume others to have. Moreover, when one successfully commands someone to do something, one changes the obligations of the addressee but no one else. So, this output normative status is also particular in the sense that the particular person addressed by the command, and no one else, acquires the obligation. In successfully commanding someone to do something, a speaker gives an obligation to a particular person (such as a subordinate).

The normative function representing asserting is thus from general input status to general output status, whereas the normative function representing commanding is from particular input status to particular output status. Many speech acts, however, are more complex in their normative input/output statuses than these simple examples suggest. Indeed, a full articulation even of the practice of asserting and commanding may reveal other normative statuses that are partially constitutive of these speech-acts within a linguistic practice that have contrasting particular or general aspects. In any case, at the most basic level, it can be useful to classify normative input conditions (what entitles a speech act) and normative output statuses (what entitlements, obligations, and reasons change as a result of an entitled performance of the speech act) as particular or general. For one thing, this helps to see the possibility of speech acts with a general input status like assertion, but particular output status like commands, and vice versa. For another, this helps to map the way complex speech acts can involve both general and particular elements in both the input and output statuses of the normative functions constituting them as the speech acts that they are. ${ }^{13}$

\footnotetext{
13 The distinction we make here between general and particular statuses is similar to Kukla and Lance's (2009) distinction between agent-neutral and agent-relative normative statuses. Since the terms 'agent-neutral' and 'agentrelative' are most commonly applied to reasons, and Kukla and Lance don't explain how that distinction maps onto normative statuses such as entitlements and obligations, we have adopted an alternative terminology that we hope is less apt to confusion.
} 
Examples of these mixed-element and complex speech act kinds are easy to come by. First, consider moral, prudential, or legal claims about what some particular person should do. Insofar as these have truth about what is morally, prudentially or legally prescribed as an entitlement condition, they might be viewed as general in their normative input condition, yet, insofar as they give obligations to some specific person, they might be viewed as particular in (at least this part of) their normative output. ${ }^{14}$ In contrast, consider the speech act of baptizing. What must be true in order for someone to be entitled to baptize something depends on the speaker's particular relation to the thing to be baptized (roughly, they must be recognized by others as having the right to name the thing in question). In baptizing something, however, the speaker creates for everyone a general obligation to call the baptized thing by its new name. ${ }^{15}$ These are examples of mixed-element speech acts; for an example of a complex speech act, consider the case of someone marrying two people. As noted above, being entitled to perform a traditional marriage requires a socially recognized status (e.g., historically in Christianity, that of being a priest), so one main consideration that entitles one to perform the speech act is particular. The output-status, in contrast, is a mix of general and particular obligations. The particular obligations include the specific obligations each member of the married couple acquires vis-à-vis the other, including (traditionally) commitments of monogamy. But, marrying people generates a general obligation for others to treat the married couple as married (for various social and legal reasons e.g. tax status, deathbed privileges, etc.). ${ }^{16} \mathrm{~A}$ complex speech-act type thus can have diverse types of input and output normative statuses.

The precise details of these examples don't matter here. What's important is to recognize the strategy of representing speech act kinds with normative functions, whose inputs and outputs can be either general or particular. We now turn back to the case of protests with this more precise normative functionalist conception of speech acts in hand. We think protests can be characterized as complex speech acts with a diversity of input and output-status types, and making these explicit can help to make the communicative structure of protest clearer than our previous appeal to felicity conditions did.

As we noted at the beginning of section 1 , an act of protest involves both

(i) an expression of opposition, and

(ii) a connected prescription for redress.

Previously, we appealed to the machinery of felicity conditions to explain these two elements. In what follows we want to refine this analysis by using the machinery of normative functionalism.

Regarding (i), previously we suggested that a protest might be viewed as claiming, either explicitly or implicitly, that its object is unfair or unjust relative to a presumed overlapping conception of what is unjust or unfair. This is why we suggested that a protest is infelicitous if the object is not the sort of thing that can be unfair or unjust. The normative functionalist approach just sketched provides a way to improve on this idea by arguing that protestors are not (mainly) making claims about what is ruled out by some conception of fairness or justice but rather negatively evaluating the object of protest in a general way. More precisely, our suggestion is that the way protests negatively evaluate the object presumes a kind of entitlement that is general rather than particular. If the object of protest is in fact bad or wrong, then it is bad or wrong in a way that would entitle anyone to express opposition, not just people with some special normative status. ${ }^{17}$ This is why it is not only the oppressed who can

\footnotetext{
14 See Kukla and Lance (2009), 100-102.

15 See Kukla and Lance (2009), 39 and 43.

16 See Kukla and Lance (2009), 20-21.

17 There may be some protests, such as Rawlsian civil disobedience, that presume something like membership in a particular constitutional community as a limitation on the entitlement to negatively evaluate the object of protest. This would be a way that the normative statuses changed by the protest would be less than fully general, as they depend on a particular relationship between the speaker and those acquiring new reasons as a result of the protest. Here we are focussed on protest writ large, but we suspect a more fine-grained treatment of particularity and generality might provide theoretical resources for distinguishing different kinds of protest.
} 
legitimately protest oppression; if oppression entitles one person to express opposition, then it entitles anyone to express opposition. Moreover, the core normative output status of element (i) of a protest is also general. A protest seeks to entitle others to also negatively evaluate the object of protest, and this is an entitlement that does not depend on who in particular those others are. Of course, a protestor may specifically want their friends and family to agree that the object of protest is wrong, and those who are directly and negatively affected are more likely to appreciate one's reasons for protesting something, but protests aim for wider persuasion based in general reasons.

So, in sum, our idea with respect to (i) is thus to draw on the normative functionalist conception of speech acts above, in order to characterize protest as having a negative evaluative element that is general in its core constitutive input and output normative statuses. It is like assertion in this regard, but we are not claiming that this element is essentially an assertion that something is unfair or unjust; rather, it is a negative evaluation of the object which is supposed to enjoy entitlement based in general reasons for opposing the object of protest and to change general entitlements for other people to similarly evaluate the object of protest without regard to who in particular those other people are. One can protest, then, without making a claim about what's true relative to a conception of fairness or justice. This makes sense of the possibility that one can protest things one thinks are wrong without even attempting to rely on a presumed overlapping conception of fairness or justice-no such considerations are relevant if one can protests the color of the national team's jersey or the closing of one's favorite bar. What is key is that in protesting one presumes a general entitlement to do so and, when successful, one changes general entitlements for others with respect to their evaluations of the object of protest.

Let's turn now to the second element of a protest. Regarding (ii), previously we floated the idea that protests prescribe redress, seeking to impose an obligation on their addressee. This suggests that protests are felicitous only if the protestor has authority to impose obligations, but then we raised the worry that it is puzzling how such authority could be enjoyed by protestors who, in order to protest at all, must lack authority over the people from whom they desire redress. The normative functionalist approach to individuating speech acts also provides a way to improve the analysis of this element of protest. Indeed, we now want to suggest that, in order to have the status to protest, the protester must not have authority, power, etc., over the addressee of the protest (at least with respect of the topic of the protest). It must be rather the addressee's prerogative, and not that of the protester, to do what is being prescribed. It is not Pussy Riot's prerogative to grant Russian citizens greater political freedom or to order Putin to do so. Were it their prerogative, they would not pursue their goals by protesting Putin, but they would instead enact their goals (perhaps by speech-act types, such as decrees). Putin, by contrast, cannot protest Pussy Riot's activities, for he has the authority to respond to any injustice or unfairness of their behavior, not by seeking redress, but by, e.g., directly punishing them. So the input status for the prescriptive element is not general. Although it is not general, it does not require that the protester be subject to the addressee's power or authority-Australians can march on the Russian embassy in Griffith to protest Putin's treatment of Pussy Riot.

On the output side, the normative statuses which are generated by the prescriptive element of a successful protest are particular, in the sense that they are obligations on particular people. However, the particularities of the people on whom the obligation is imposed are clearly different than standard examples of commands. As just noted, the addressee of a protest ought to be someone with authority or control over the prescribed redress to the protest, and a protest assumes they have general rather than particular reasons to give the prescribed redress. This helps us see more clearly why the disgruntled traveler from the previous section is better seen as complaining rather than protesting his unfortunate situation. If the airline employee to whom he is complaining were to put him on the flight, they would have to bump someone else, which the traveler knows. This suggests that whatever reasons there are to give redress in this case are particular to the employee's relationship with the traveler rather than something general, such as what is based in what's fair or for the common good. Moreover, if the traveler is simply ignoring the meteorological facts of the situation-imagine him saying, "I 
don't care that you can't take off in this weather-I have to get home tonight, and you have to get me there!"- - then the case is one of complaint, and not protest, because there cannot be an appropriate addressee for the protest. The proper addressee of a protest is someone who has some sort of status that allows them to react to and/or affect the object of protest and who is not using or has not used this power in the way that the protester thinks they should. In this last case, the traveler cannot direct his addressee to use their normative powers in a certain way, because the relevant normative powers simply do not exist-no one controls or is responsible for the weather. In this case, then, there is no proper addressee for the speech act, and so there can be no protest.

\section{Conclusion}

Understanding protest is a topic for non-ideal political philosophy, but protests are clearly communicative acts, which makes this also a topic for applied philosophy of language. In this paper, we have sought to use the resources of speech act theory to better understand the communicative aspects of protest because we think these will be useful for evaluating the justifiability of various protests in various non-ideal political circumstances. We pursued our analysis in three stages. First, we distinguished the object, redress, and means of a protest. This provided a way to think of atomic acts of protest as having dual communicative aspects, viz., a negative evaluation of the object and a connected prescription of redress. Second, we used Austin's notion of a felicity condition to further characterize the dual communicative aspects of protest. This allowed us to distinguish protest from some other speech acts which also involve a negative evaluation of some object and a connected prescription of redress. However, several questions remained. We thus turned to Kukla and Lance's idea of a normative functionalist analysis of speech acts to advance the view that protests are a complex speech act constituted by dual input normative statuses and dual output normative statuses, with some general elements and some particular elements. On the input side, we have claimed that a protest presumes entitlement to negatively evaluate the object of protest (where we think this has something to do with general grounds that pertain to everyone and not just the protestor), and a protest presumes entitlement to prescribe redress from the addressee (where we think that has something to do with grounds for imposing the obligation that derives from the wrong claimed in the object of protest rather than from one's status as having authority over the addressee). On the output side, we have claimed a successful protest generates entitlements and reasons for others to negatively evaluate the object of protest (where we think this has something to do with general grounds that go for everyone or everyone in the audience), and a successful protest generates obligations for the addressee to perform redress (where we think this has something to do with particular grounds that apply only to the addressee of the protest and no one else because of their authority or control over the prescribed redress).

\section{Works Cited}

Austin, J. L. (1975). How to do things with words. Cambridge: Harvard University Press.

Brandom, R. 1983. Asserting. Noûs 17: 637-50.

Brandom, R. (1994). Making it explicit. Cambridge: Harvard University Press.

Chrisman, M. and Hubbs, G. (2018). Speaking and listening to acts of political dissent. In C. R. Johnson (ed.), Voicing dissent: The ethics and epistemology of making disagreement public, New York: Routledge, 164-81. 
Delmas, C. (2018). A duty to resist: When disobedience should be uncivil. New York: Oxford University Press. Finlay, S. (2014). Confusion of tongues: A theory of normative language. New York: Oxford University Press. Goldberg, S. (2015). Assertion: On the philosophical importance of assertoric speech. New York: Oxford University Press.

Green, M. and Williams, J. (Eds.). (2007). Moore's paradox: New essays on belief, rationality, and the first person. New York: Oxford University Press.

Hubbs, G. (2019). Anscombe on how St. Peter intentionally did what he intended not to do. American Catholic Philosophical Quarterly 93: 129-45.

Kukla, R. and Lance, M. (2009). Yo! and Lo! The pragmatic topography of the space of reasons. Cambridge, MA: Harvard University Press.

Lewis, D. (1979). Scorekeeping in a language game. Journal of Philosophical Logic 8: 339-59.

Langton, R. \& West, C. (1999). Scorekeeping in a pornographic language game. Australasian Journal of Philosophy 77 (3):303 - 319.

MacFarlane, J. 2011. What is assertion? In Assertion, eds. J. Brown and H. Cappelen,

79-96. Oxford: Oxford University Press.

Moore, G. E. (1942). A reply to my critics. In P. A. Schlipp (ed.), The philosophy of G. E. Moore Evanston: Northwestern University Press.

Rawls, J. (1999a). A theory of justice. Cambridge: Harvard University Press.

Rawls, J. (1999b). The law of peoples. Cambridge: Harvard University Press.

Rescorla, M. 2009. Assertion and constitutive norms. Philosophy and Phenomenological Research 79: 98-130.

Searle, J. (1975). A taxonomy of illocutionary acts. In K. Gunderson (ed.), Language, mind, and knowledge: Minnesota studies in philosophy of science, vol. 15, Minneapolis: University of Minnesota Press, 34469.

Sellars, W. (1956/1997). Empiricism and the philosophy of mind. Cambridge: Harvard University Press. Shelby, T. (2016). Dark ghettos: Injustice, dissent, and reform. Cambridge: Harvard University Press. Stanley, J. (2018). How propaganda works. Princeton: Princeton University Press.

Woods, J. (2014). Expressivism and Moore's Paradox. Philosopher's Imprint 14(5): 1-12. 